数值流体解析における境界条件の統一的な取扱いについて

A Unified Treatment of Boundary Conditions in Numerical Analysis of Fluids

北海道大学工学部 水田 洋 Yo MIZUTA

In computational fluid dynamics, various boundary conditions are used, and some of them have required special treatments. Free surfaces, density interfaces, and open boundaries encountered in hydraulic numerical analysis are those examples. On the basis of a deformable-cell method, in which cells dividing the incompressible fluid can deform according to the moving boundaries, most boundary conditions are considered on a "generalized boundary equation," and they can be treated in a unified manner. The density stratified shear flow at a river mouth is simulated numerically by this method, and each boundary is shown to behave as expected.

Keywords: numerical analysis, free surface, density interface, open boundary, stratified flow

1.はじめに

水理学, 海岸工学なとの分野における数值解析では, 栐々な種類の境界条件を扱うことが多い.たとえば 河口密度流の問題で, 自由表面と密度界面の形が河川流量や河口潮位の時間变化の影響を受けてどのように 変わるのかを調べる場合には，次のような境界条件に出会う。

（NV) 河床, 流入など境界上の法線流速が既知, (NP) 自由表面, 流出など境界上の圧力が睡知, (NI) 密度界 面など境界上の法線流速と圧力が共に未知だが連続，(NZ) 塭水先端のように長さのない境界，(SV)滑りのな い壁面のように接線流速が䀣知，(SS) 滑りのある壁面や風応力がある場合のように接線応力が䀣知，(SI）密 度界面なとで連続な接線流速を内拥. さらに数值解析領域を関心のある領域に限ると, (NO) (SO) 開いた境界, も必要になる.ここで()内は, 境界条件の種類を示すために本研究で用いている記号である.

従来, このうちの自由表面・密度界面などは, MAC法などで行われているように, 他の境界とは異なる方法 によって报われてきた。それは主に，これらの境界は時間と共に形を変えるのに，流体を分けている格子が 規則的で变形しないからである.しかし，流体を変形可能なセルに分け，数值解析式を糟分型の保存則から 毞く「変形可能セル法」を用いると, 自由表面・密度界面・開いた境界なども含めて各種の境界条件が統一 的に扱われるようになる [1-4] . 本論文では, まず变形可能セル法の概要をまとめ, 次いで境界条件を統一 的に扱うために基本となる考え方を述べる．特に，現在㦈論の多い「開いた境界」が，この考え方でどのよ うに报われるかを紹介する，最後に，河口密度流に関する数値解析の実行結果を報告する.

\title{
2. 変形可能セル法の概要
}

変形可能セル法の主要な部分を整理してまとめると, 次のようになる [1-4] . 流体を図 1 のような任意形 状の変形可能なセル（小胞）に分ける. 流体の厚みはセル毎に変わっていてもよい. セルの形は一般四角形 としておくのが便利である.ここでセルには，そのセルが受け持つ流体の体糟 $V$ ，筫量 $M$ ，運動量 $M v$ とそ れらから求めた流体の密度 $\rho_{\mathrm{o}}=M / V$, 速度 $v_{\mathrm{o}}=M v / M$ などを割り当て, 添え字 $\mathrm{c}=\mathrm{A}, \mathrm{B}, \ldots$ をつける. 一方項点

（格子点）には, $\rho_{\mathrm{c}}, v_{\mathrm{c}}$ の内捅から求めた $\rho_{\mathrm{v}}, v_{\mathrm{v}}$, 頂点の移動速度 $u_{\mathrm{v}}$, 圧力 $p_{\mathrm{v}}$ などを圈き, $v=1,2, \ldots て ゙$ 識 別する.

数值解析式は, 体積, 䝷量, 運動量に対する積分型の保存則から導く.セルにおける筫量, 運動量保存則 は, 時間ステップ $n$ における量から時間 $\Delta t$ だけ後のステップ $n+1$ における量を求めるために用いる. 


$$
\begin{aligned}
& M^{n+1}=M^{n}+[\oint d S \cdot(u-v) \rho]^{n} \Delta t+(\text { 拡散項 })^{n} \Delta t, \\
& (M v)^{(n)}=(M v)^{n}+[\oint d S \cdot(u-v) \rho v]^{n} \Delta t+[(\text { 粘性項 })+(\text { 重力項 })]^{n} \Delta t, \\
& (M v)^{n+1}=(M v)^{(n)}-(\oint d S p)^{n+1} \Delta t .
\end{aligned}
$$

表面䆏分 $\oint d S$ の箅囲はセルの全表面にわたり, 紝面に垂直な側面と, 紙面に 平行に近い上面・下面とに分かれる. 側面の糟分は, 流体の厚さ, 側面内の微 小变位ベクトルの紙面内成分, 紙面に垂直な単位ベクトルを $b, d r, z$ とすれば 線積分 $\oint b d r \times \boldsymbol{z}$ で嘈き換えられる. 一方上面・下面の積分は，表面上で $u=v=0$ となる対流流束項や後述の体積保存則では 0 となる.

式（3）の両辺に $(b / M)^{n+1}$ をかけて，次のような稓分流速 $q^{n+1}$ を定義する.

$$
\begin{aligned}
& q_{\mathrm{A}, \mathrm{B}, \mathrm{C}, \mathrm{D}}^{n+1}=q_{\mathrm{A}, \mathrm{B}, \mathrm{C}, \mathrm{D}}^{(n)} f_{\mathrm{A}, \mathrm{B}, \mathrm{C}, \mathrm{D}}^{n+1} \Delta t, \\
& \left.q^{n+1} \equiv\left[\frac{b}{M}(M v)\right]^{n+1}, q^{(n)} \equiv\left(\frac{b}{M}\right)^{n+1}(M v)^{(n)}, \quad f_{\mathrm{C}} \equiv\left(\frac{b}{M} \oint d S p\right)\right)_{\mathrm{C}}=\left(\frac{b^{2}}{2 M}\right)_{\mathrm{C}}\left[\begin{array}{c}
p_{5} r_{24}+p_{2} r_{15} \\
+p_{4} r_{51}+p_{1} r_{42}
\end{array}\right] \times z .
\end{aligned}
$$

ここで，压力項 $\boldsymbol{f}$ の表面䄼分のうち，㑯面糟分を先に述べたように線糟分で置き換える．また上面・下面の 箖分は， $b$ が各頂点で等しけれは，值が 0 となる.このとき， $f$ は上の式のように単純になる．ただし, 点 24 間の変位ベクトルを $r_{24}$ のように表している，b の大きさが頂点毎に異なるなら，上面・下面の積分も 値を持つので $f$ の形はもっと複雜になるが, セル周囲の 4 項点上の圧力 $\left(f_{\mathrm{C}}\right.$ では $\left.p_{1,2,4,5}\right)$ の線型結合で表 されることに変わりはない.

ところで非圧縮性流体では，以下の式(5)の第 1 辺，第 2 辺で表される体積保存則が成り立っている。これ をセルにおいてではなく，図 1 に破線で示すような, 項点を囲む体積保存則適用領域で考える. 第 2 辺の側 面上の積分を線積分になおし，式 (4)で定義した糟分流速を使うと, これは第 4 辺のように $q_{\mathrm{A}, \mathrm{B}, \mathrm{C}, \mathrm{D}}$ の線型結 合で表される. 式(6)は，式(5)第 4 辺の各々のq ${ }^{n+1}$ に式(4)を代入したものである. 特に第 2 項を各々のf に4つずつ含まれているゃ について整理すれば, $p_{1-9}$ の線型結合になる.

$$
\begin{aligned}
& 0=(\oint d S \cdot v)^{n+1}=(\oint q \times d r)^{n+1} \cdot z=\Delta V\left(\left\{q^{n+1}\right\}\right) \\
& =\Delta V\left(\left\{q^{(n)}\right\}\right)-\Delta V\left(\left\{f^{n+1}\right\}\right) \Delta t, \\
& \Delta V(\{q\}) \equiv \frac{1}{2}\left[\begin{array}{r}
q_{\mathrm{A}} \times r_{\mathrm{DB}}+q_{\mathrm{D}} \times r_{\mathrm{CA}} \\
+q_{\mathrm{B}} \times r_{\mathrm{AC}}+q_{\mathrm{C}} \times r_{\mathrm{BD}}
\end{array}\right] \cdot \boldsymbol{z}, \Delta V(\{f\})=\frac{1}{2}\left[\begin{array}{c}
f_{\mathrm{A}} \times r_{\mathrm{DB}}+f_{\mathrm{D}} \times r_{\mathrm{CA}} \\
+f_{\mathrm{B}} \times r_{\mathrm{AC}}+f_{\mathrm{C}} \times r_{\mathrm{BD}}
\end{array}\right] \cdot \boldsymbol{z}=\frac{1}{2}\left[\begin{array}{c}
A_{8} p_{9}+A_{6} p_{\mathrm{B}}+A_{3} p_{3} \\
+A_{8} p_{8}+A_{5} p_{5}+A_{2} p_{2} \\
+A_{7} p_{7}+A_{4} p_{4}+A_{1} p_{1}
\end{array}\right] .
\end{aligned}
$$

式(4)の $q^{(n)}$ は体樌保存則を满たさないので,これに圧力項 $f^{n+1}$ を加えて, $q^{n+1}$ が体積保存則を满たす ようにしたい. $f^{n+1}$ の計算に必要な各頂点上の圧力p はこの段階ではまだ未知である. 式(6)はp を求め るための「圧力方程式」であり，右辺第 1 項は䀣知, 第 2 項は 9 つの未知量を含む. 数值解析頜域内の頂点を 团む全ての体糟保存則適用領域から導いた圧力方程式を連立させて解きゃ を求めるが，このとき未知量と方 程式の数は常に一致している.

\section{3.一般化された境界方程式と备境界条件の扱い方}

ここでは，図 2 のような境界近傍の領域で，表 1，2のような各種の境界条件を考える. 図 2 では，矢印 右側の太線領域に着目するが, 密度界面も境界の一つに扱うので, この場合は, 矢印左側の領域を補って考 える. 表 1，2 に揭げた境界条件には，2 文字の英字による記号を次のようにつけてある．最初の英字 N， Sは, 各境界に 1 つずつ互いに独立に与えられる法線および接線境界条件を表す. 次の英字は主に, 流速 
(Velocity) と压力（Pressure）または応力（Stress）のいずれ を䀣知とするかを示したものであるが，界面（Interface），長さ 0（Zero），開いた境界（Open）も含まれている.この表には，そ れぞれの境界条件の既知量と末知量も示してある.

境界上の流速 $q_{\mathrm{A}, \mathrm{B}}$ が末知な場合は, 図 2 で内側の流速 $q_{\mathrm{D}, \mathrm{c}}$ あるい は $\boldsymbol{q}_{\mathrm{B}, \mathrm{F}}$ が定まった後に, これらから境界上の流速を求めなければな らない，このとき，境界でもやはり体積保存則を成立させるには， 圧力方程式から力 を求める際に，既に境界条件が考慮されていなけ ればならない。ここでは,このために必要な「一般化された境界方 程式」を導く。

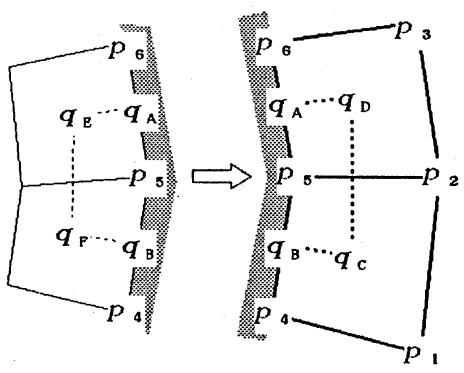

因2.境界上の体積保存則 適用領域（破線）
表 1. 法線境界条件

\begin{tabular}{|c|c|c|}
\hline $\begin{array}{l}\text { 境界 } \\
\text { 条件 }\end{array}$ & $\begin{array}{l}\text { 流速 } \\
q_{\mathrm{n}}^{0} \boldsymbol{q}_{\mathrm{n}}\end{array}$ & $\begin{array}{c}\text { 圧力 } \\
\boldsymbol{p}\end{array}$ \\
\hline $\mathrm{NV}$ & 0 & $x$ \\
\hline NP & $x$ & 0 \\
\hline $\mathrm{NI}$ & $\times$ & $x$ \\
\hline $\mathrm{NZ}$ & $x$ & $x$ \\
\hline NO & $O \times$ & $x$ \\
\hline
\end{tabular}

表 2. 接線境界条件

\begin{tabular}{|c|c|c|}
\hline $\begin{array}{c}\text { 境界 } \\
\text { 条件 }\end{array}$ & $\begin{array}{c}\text { 流速 } \\
\boldsymbol{q}_{\mathbf{a}}\end{array}$ & $\begin{array}{c}\text { 応力 } \\
\boldsymbol{\sigma}_{\mathbf{s}}\end{array}$ \\
\hline SV & $\bigcirc$ & $\times$ \\
SS & $\times$ & $\bigcirc$ \\
SI & $\times$ & $\times$ \\
SO & $\times$ & $\times$ \\
\hline
\end{tabular}

$O:$ 既知, $x:$ 未知

表 3. 各種境界条件の境界条件関数と圧力項係数

\begin{tabular}{|c|c|c|c|}
\hline $\begin{array}{l}\text { 境界 } \\
\text { 条件 }\end{array}$ & $\begin{array}{l}\text { 境界条件関数 } \\
C_{\mathrm{n}, \mathrm{s}}\left(Q_{\mathrm{D}}, Q_{\mathrm{B}}\right)\end{array}$ & $\begin{array}{l}\text { 圧力項係数 } \\
\left(K_{\mathrm{n}, \mathrm{s}}\right)_{\mathrm{A}}\end{array}$ & $\begin{array}{l}\text { 圧力項係数 } \\
\left(K^{\prime}{ }_{\mathrm{n}, \mathrm{s}}\right)_{\mathrm{A}}\end{array}$ \\
\hline SV & $q_{\mathrm{s}}$ & 0 & 0 \\
\hline SS & $\left(\frac{b \sigma_{\mathrm{s}} \Delta n}{\mu}\right)_{\mathrm{A}}+\frac{b_{\mathrm{A}_{\mathrm{A}}}}{b_{\mathrm{D}}} \mathbf{s}_{\mathrm{A}} \cdot Q_{\mathrm{D}}$ & $\frac{{ }^{b}{ }_{\mathrm{A}}}{b_{\mathrm{D}}} \mathbf{S}_{\mathrm{A}}$ & 0 \\
\hline SI & $s_{\mathrm{A}} \cdot \frac{r_{\mathrm{AB}} Q_{\mathrm{D}}+r_{\mathrm{DA}} Q_{\mathrm{E}}}{r_{\mathrm{DE}}}$ & $\frac{r_{\mathrm{AB}}}{r_{\mathrm{DE}}} \mathrm{s}_{\mathrm{A}}$ & $\frac{r_{\mathrm{DA}}}{r_{\mathrm{DE}}} \mathrm{s}_{\mathrm{A}}$ \\
\hline $\begin{array}{l}\text { NO } \\
\text { SO }\end{array}$ & $\begin{aligned}\left(q_{\mathrm{n}, \mathrm{s}}\right)_{\mathrm{A}}^{n} & +\left( \pm\left|\nabla q_{\mathrm{n}, \mathrm{s}}\right|\right)_{\mathrm{A}}^{n} \\
& \times L_{\mathrm{D}}^{n} \cdot\left(Q_{\mathrm{D}}-q_{\mathrm{D}}^{n}\right)\end{aligned}$ & $\begin{aligned} & \left( \pm\left|\nabla q_{\mathrm{n}, \mathrm{s}}\right|\right)_{\mathrm{A}}^{n} \\
\times & L_{\mathrm{D}}^{n}\end{aligned}$ & 0 \\
\hline
\end{tabular}

図 2 に破線で示すような，境界に接する体糟保存則適用領域で，式(5)を考える．このとき，境界の法線お よび接線単位べクトルを $n \mathrm{~s}$ として，境界上の積分流速を $q=\left(q_{\mathrm{n}}^{e}+q_{\mathrm{n}}\right) n+q_{\mathrm{s}} \mathrm{s}$ と表しておく.ここで法線流

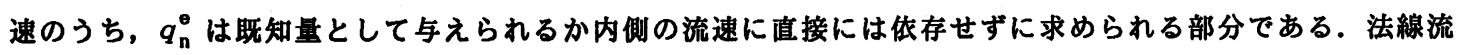
速の残りの部分 $q_{\mathrm{n}}$ および接線流速 $q_{\mathrm{s}}$ は, 表 1,2 に示すとおり, 盶知であることも, 未知で内側の流速に依 存することもあるが, いずれであっても，次の式(7)の 1 行目のように， $q_{\mathrm{n}, \mathrm{s}}$ を内側の流速に関する一次式 から求める形に表すことができる.

$$
\begin{aligned}
&\left(q_{\mathrm{n}, \mathrm{s}}\right)_{\mathrm{A}}^{n+1}=\left(q_{\mathrm{n}, \mathrm{s}}\right)_{\mathrm{A}}^{<n>}+\left(K_{\mathrm{n}, \mathrm{s}}\right)_{\mathrm{A}} \cdot q_{\mathrm{D}}^{n+1}+\left(K_{\mathrm{n}, \mathrm{s}}^{\prime}\right)_{\mathrm{A}} \cdot q_{\mathrm{B}}^{n+1} \equiv C_{\mathrm{n}, \mathrm{s}}\left(q_{\mathrm{D}}^{n+1}, q_{\mathrm{B}}^{n+1}\right) \\
&=\left(q_{\mathrm{n}, \mathrm{s}}\right)_{\mathrm{A}}^{(n)}-\left(K_{\mathrm{n}, \mathrm{s}}\right)_{\mathrm{A}} \cdot f_{\mathrm{D}}^{n+1} \Delta t-\left(K_{\mathrm{n}, \mathrm{s}}^{\prime}\right)_{\mathrm{A}} \cdot f_{\mathrm{B}}^{n+1} \Delta t, \\
&\left(q_{\mathrm{n}, \mathrm{s}}\right)_{\mathrm{A}}^{(n)} \equiv C_{\mathrm{n}, \mathrm{s}}\left(q_{\mathrm{D}}^{(n)}, q_{\mathrm{B}}^{(n)}\right) .
\end{aligned}
$$

ここでは $q_{\mathrm{n}}$ の形を $q_{\mathrm{B}}$ に揃えてあるが， $q_{\mathrm{n}}$ は専ら(N0)で使われるので，実際には $q_{\mathrm{B}}$ には侬存することなく， $K_{n}^{\prime}$ も0である. 表 $3 に$ ，各種の境界条件に対する境界条件関数 $C_{\mathrm{n}, \mathrm{s}}\left(Q_{\mathrm{D}}, Q_{\mathrm{B}}\right)$ および圧力項係数 $\left(K_{\mathrm{n}, \mathrm{s}}\right)_{\mathrm{A}}$ ， $\left(K_{\mathrm{n}, \mathrm{s}}^{\prime}\right)_{\mathrm{A}}$ の具体的な形をまとめてある. ところで内側の流速は, 式(4)のように圧力項を含む. このため $\left(q_{\mathrm{n}, \mathrm{s}}\right)_{\mathrm{A}}^{n+1}$ も, $f_{\mathrm{D}}^{n+1}$ または $f_{\mathrm{B}}^{n+1}$ に体存することになるが, それは式(7)の 2 行目のように表される. なお ここでは, $\left(q_{\mathrm{n}, \mathrm{s}}\right)_{\mathrm{A}}, q_{\mathrm{D}}, q_{\mathrm{B}}$ について述べたが, $\left(q_{\mathrm{n}, \mathrm{s}}\right)_{\mathrm{B}}, q_{\mathrm{C}}, q_{\mathrm{F}}$ の間にももちろん同様の関係がある.

以上の関係をもとに，式(5)第 4 辺の $\Delta V$ を变形する，まず，境界上の流速 $q_{\mathrm{AB}}$ を法線および接線流速で表 して, 式(8)のようにまとめる. 更に,これに式(7)を(4)と共に代入して, 式(9)を導く.こうして得られた 
のが次の「一般化された境界方程式」である。

$$
\begin{aligned}
& 0=\Delta V\left(\left\{q^{n+1}\right\}\right)=\Delta V_{B}\left(\left\{q^{n+1}\right\}\right)+\left(q_{\mathrm{n}}^{\bullet} \Delta S\right)_{5}^{n+1} \\
& =\Delta V_{B}\left(\left\{q^{(n)}\right\}\right)+\left(q_{n}^{e} \Delta S\right)_{5}^{n+1}-\Delta V_{B}\left(\left\{f^{n+1}\right\}\right) \Delta t . \\
& \Delta V_{\mathrm{B}}(\{q\}) \equiv \frac{1}{2}\left[\begin{array}{c}
\left(q_{\mathrm{n}} \Delta s-q_{\mathrm{s}} \Delta n\right)_{\mathrm{A}}+\left(q_{\mathrm{D}} \times r_{\mathrm{CA}}\right) \cdot z \\
+\left(q_{\mathrm{n}} \Delta s+q_{\mathrm{s}} \Delta n\right)_{\mathrm{B}}+\left(q_{\mathrm{C}} \times r_{\mathrm{BD}}\right) \cdot z
\end{array}\right], \quad\left(q_{\mathrm{n}}^{\mathrm{e}} \Delta S\right)_{\mathrm{b}} \equiv \frac{\left(q_{\mathrm{n}}^{e} \Delta S\right)_{\mathrm{A}}+\left(q_{\mathrm{n}}^{\mathrm{e}} \Delta S\right)_{\mathrm{B}}}{2}, \\
& \Delta V_{\mathrm{B}}(\{f\})=\frac{1}{2}\left[\begin{array}{c}
\left(-K_{\mathrm{s}}^{\prime} \Delta n\right)_{\mathrm{A}} \cdot f_{\mathrm{B}}+\left\{\left(K_{\mathrm{n}} \Delta S-K_{\mathrm{B}} \Delta n\right)_{\mathrm{A}}+r_{\mathrm{CA}} \times z\right\} \cdot f_{\mathrm{D}} \\
+\left(K_{\mathrm{s}}^{\prime} \Delta n\right)_{\mathrm{B}} \cdot f_{\mathrm{F}}+\left\{\left(K_{\mathrm{n}} \Delta S+K_{\mathrm{B}} \Delta n\right)_{\mathrm{B}}+r_{\mathrm{BD}} \times z\right\} \cdot f_{\mathrm{C}}
\end{array}\right]=\frac{1}{2}\left[\begin{array}{c}
A_{6} p_{6}+A_{3} p_{3} \\
+A_{5} p_{5}+A_{2} p_{2} \\
+A_{4} p_{4}+A_{1} p_{1}
\end{array}\right] \text {, } \\
& \Delta s_{\mathrm{A}} \equiv \mathrm{s}_{\mathrm{A}} \cdot r_{\mathrm{DB}^{\prime}} \quad \Delta n_{\mathrm{A}} \equiv n_{\mathrm{A}} \cdot r_{\mathrm{DB}^{\prime}} \quad \Delta s_{\mathrm{B}} \equiv \mathrm{s}_{\mathrm{B}} \cdot r_{\mathrm{AC}} \quad \Delta n_{\mathrm{B}} \equiv-n_{\mathrm{B}} \cdot r_{\mathrm{AC}} \quad \Delta s_{5} \equiv\left(\Delta s_{\mathrm{A}}+\Delta s_{\mathrm{B}}\right) / 2 .
\end{aligned}
$$

境界方程式の第 3 項は，(SI) 以外では $K_{\mathrm{s}}{ }_{\mathrm{s}}$ が 0 となるので, $p_{1-6}$ の線型結合となる. 第 1 項は睡知なので， これは第 2 項の $\left(q_{n}^{e}\right)_{5}^{n+1}$ と $p_{1-6}$ を末知量とする方程式である.この境界方程式は, 圧力方程式と連立させて 解く際にどの境界でも共通に用いられるが，その扱い方は，以下に述べるように境界条件毎に異なっている. (NV) $q_{\mathrm{n}}^{\text {e }}$ 睡知として压力方程式と境界方程式を解けば， $p_{4-6}$ が求められる. (NP)圧力方程式を解く時は $p_{4-6}$ を䀣知とし， $q_{\mathrm{D}, \mathrm{c}}$ と $\left(q_{\mathrm{B}}\right)_{\mathrm{A}, \mathrm{B}}$ が決まった後に式 $(8)$ から $q_{\mathrm{n}}^{\mathrm{e}}$ を求める. (NI) 対になる図 2 矢印左側の領 域との間で $p_{4-6}$ と $q_{\mathrm{n}}^{\mathbf{e}}$ の連続条件を仅定し，匠力と同時に法線流速も求める.（NZ)計算領域の境界上にある 複数の頂点とその上の圧力は, 物理領域では全て同一である. 未知量と方程式の数を一致させるため, この 境界上の境界方程式の総和式を改めて圧力方程式と連立させる. (SS) 式 (7)における仮の接線流速 $\left(q_{\mathrm{B}}\right)_{\mathrm{A}, \mathrm{B}}^{(n)}$ で 境界方程式の第 1 項を計算し, 圧力を求めた後に, $\boldsymbol{q}_{\mathrm{D}, \mathrm{C}}^{n+1}$ から真の $\left(q_{\mathrm{B}}\right)_{\mathrm{A}, \mathrm{B}}^{n+1}$ 計算し直す. (SI) 界面をはさん で対になる体箖保存則道用領域を考えると，2本の境界方程式は，もともと相手方の領域の圧力を含んでい る. しかし、これらから連続な $q_{\mathrm{n}}^{\mathrm{e}}$ を消去して得た 1 本の式を, 再び, $\boldsymbol{q}_{\mathrm{D}, \mathrm{c}}$ だけあるいは $\boldsymbol{q}_{\mathrm{B}, \mathrm{F}}$ だけを含む 2 本の式に分離して，各々の式が相手方の領城の圧力を含まないようにできる.こうすれば, 未知量に関して は式(9) と構造が同じになり，圧力方程式の解法が简単になる， $q_{\mathrm{n}}^{\mathbf{e}}$ は $q_{\mathrm{D}, \mathrm{c}}$ と $\left(q_{\mathrm{B}}\right)_{\mathrm{A}, \mathrm{B}}$ が決まった後に式(8) から求める. なお, (NO)（SO)については, 次の節で述べる.

圧力方程式と境界方程式を連立させて解くに当たっては,これらがちょうど差分化されたPoisson方程式と 同じ構造となっているため, 各種の直接解法, 反復解法を利用できるが, ここでは, 直接解法の一つである EV P 法 [4,5] を使っている.

\section{4.開いた境界について}

開いた境界 (NO) (SO)の扱い方を考えるため, ここでは特性曲線法から入り, 他の方法と関連づけながら数 值解析式を導く. 法線流速, 接線流逨なとの物理量を $F$ ，境界付近の波速（情報伝達速度）ベクトルを $c$ ， $F$ の勾配 $\nabla F$ と平行な単位ベクトルを $k$ とすれは，時刻 $t+\Delta t$ における境界上の点 $r_{\mathrm{A}}$ での $F$ を求めるため には，時間で $\Delta t$ だけ前へ空間で-c $\Delta t$ だけ内侧へ遡れはよい，このことは，下の式(10)のように表されるが， $\Delta t$ が小さいとしてTayler展開を行うと、これは更にSommerfeldの放射条件 $\frac{\partial F}{\partial t}+c \cdot \nabla F=0$ の差分形にあたる 式(11)のようになる．すなわち，開いた境界付近でF に対して(12)のような関数形を仅定することになる.

$$
\begin{aligned}
F_{\mathrm{A}}^{m+1} & =F\left(r_{\mathrm{A}} t+\Delta t\right)=F\left(r_{\mathrm{A}}-c \Delta t, t\right) \\
& \approx F\left(r_{\mathrm{A}^{\prime}} t\right)-c \Delta t \cdot \nabla F\left(r_{\mathrm{A}^{\prime}} t\right)=F_{\mathrm{A}}^{m}-c \Delta t \cdot k( \pm|\nabla F|)_{\mathrm{A}^{\prime}}^{n} \\
F= & F(\theta), \quad \theta=k \cdot(r-c t) .
\end{aligned}
$$

波速ベクトルの決め方が次に間題となるが, そのために, $r_{\mathrm{A}}$ と一つ内側の点 $r_{\mathrm{D}}$ で $c, k$ が等しいことを仮 定する.この時, 法線流速と接線流速とで波速が異ならないようにこれらを対称的に含む $G=q_{\mathrm{n}}^{2}+q_{\mathrm{B}}^{2} に$ 着目し， またc 自身の代わりにc とk の内箖を求める.

$$
-c \Delta t \cdot k=\frac{G_{\mathrm{D}}^{n+1}-G_{\mathrm{D}}^{n}}{( \pm|\nabla G|)_{\mathrm{D}}^{n}}=L_{\mathrm{D}}^{n} \cdot\left(q_{\mathrm{D}}^{n+1}-q_{\mathrm{D}}^{n}\right), \quad L \equiv \frac{1}{ \pm|\nabla G| \delta q}=\frac{2 q}{ \pm|\nabla G|} .
$$


これを式(11)に代入し，F を $q_{\mathrm{n}, \mathrm{a}}$ で嘈き換え，式(7) と比較すれば, 表 3 に示した境界条件関数と圧力項係 数が導かれる.こうして, 開いた境界が統一的な境界条件の一つとなっていることが示された。

開いた境界を报うもう一つの方法は, 式 (12)を前提として, 内捅法で関数 $F(\theta)$ の形と共に波速の大きさ を決めるものである．波速ベクトルとF の勾配が境界に垂直で，D A間でF は二次関数で内捅できると仮定 する.このとき, $F_{\mathrm{A}}^{m}, F_{\mathrm{D}}^{m},\left(F^{m}-F^{m-1}\right)_{\mathrm{A}},\left(F^{m}-F^{m-1}\right)_{\mathrm{D}}$ の值を 4 つの条件として, 内拝関数の 3 つのパラメー ターの值と波速の大きさ $|c| \Delta t$ を決めることができる。この $|c| \Delta t$ を式(11)に代入して求めた $\left(q_{\mathrm{n}, \mathrm{s}}^{n+1}\right)_{\mathrm{A}}$ は, 前の方法とは対照的に $q_{\mathrm{D}}^{n+1}$ を含まないので，開いた境界は，(NV) (SV) と同等に扱うことができる.

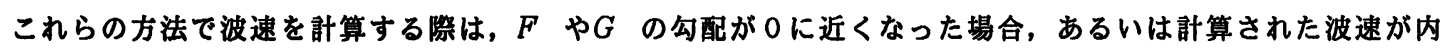
向きになったり，大きくなってCourant条件を满たさなくなる場合の適切な処理が必要になる.ここでは, 前 者については勾配が０から離れるまでそれ以前のステップの波速を使い，後者については０より小さかった

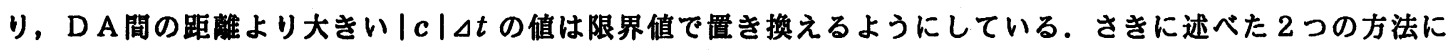
これらの処理を取り込むとき，先の方法より後の方法の方が $q_{\mathrm{D}}^{n+1}$ を含まない分だけ容易なため,ここでは後 の方法を採用している.

ところで，長波方程式を用いる場合の開いた境界についてはいくつかの方法が知られているが [6]，それ らは,ここで出発点にした特性曲線法，あるいはSommerfeldの放射条件を用いることと等価である [7] . したがって,ここに示した方法は, 長波方程式で扱われる波浪や津波などの間題にとっても充分なものに なっている，なお，開いた境界は，数值解析領域内部からの波や流れを外へ出すばかりでなく，外部流速， 外部圧力を領域内に入れる機能も持つものであろう.これは, 式(10)-(13)のF や $G$ に外部からの寄与を除 く部分を用いることで実現できるとみられるが, この点は現在檢討中である.

\section{5. 河口密度流の数值解析}

これまで述べてきた方法を用い, 図 3 のような領域で河口密度流の数值解析を行った. 淡水は左端（上 流）から右端（河口）まで存在するが, 盗水は右端から領域の途中までしか僈入していないため, 自由表面, 密度界面, 一層領域, 二層領域, 塭水先端部, 岦断流などが混在することになる。この図には, 法線および 接線境界条件も記入してある. 河口潮位の変化として，右端で表面と界面の高さを最初から 4 時間後までは 上昇，その後下降させて 8 時間後に元に戻す場合を， $\Delta t=30$ 秒で計算した. 図 4 は，このときの表面（左 図）と界面（右図）の形の時間変化を示しているが, これによれば, 上流境界は表面波に対して開いた境界 としての性筫を備えていることがわかる。 また，潮位の上昇と共に遡上した塩水先端部は，潮位の下降後も その場に留まっている.ただ,この時先端付近で塩水の厚さは極めて薄く，定常的な流れがあると速やかに 下流へ移動するものと思われる．図 5 は，左端表面の波速と水平流速，および各地点の水位と界面高の時間 変化である. 計算された波速は, ここでは割合落ち着いた值となっている，なお最初の変動は，静水状態を 初期条件としたことによる. 河口潮位が下がると塩水の体積が減少するため，体積保存則を满たすように淡 水が右端からだけでなく，左端からも領域内に引き込まれる．左端の水平流速が 6 時間より後に負になるの は,このような理由による。

\section{6. 結 詅}

河口密度流の数値解析にみられるような各種の境界条件は, 变形可能セル法に基づく一般化された境界方 程式を用いた定式化により，統一的に扱えることを示すことができた。これにより，プログラム作成，テ バッキングの労カが減り，計算精度の予測が容易になって計算時間やメモリーを必要以上に費やさずにすむ. また，一旦作成したブログラムを別の問題で再利用したり，より洗練された方法の発見へつなくこことも可能 であろう。 


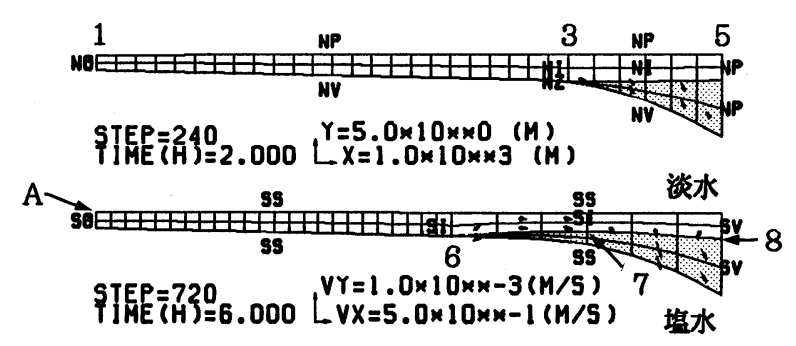

図 3. 数値解析領域と境界条件

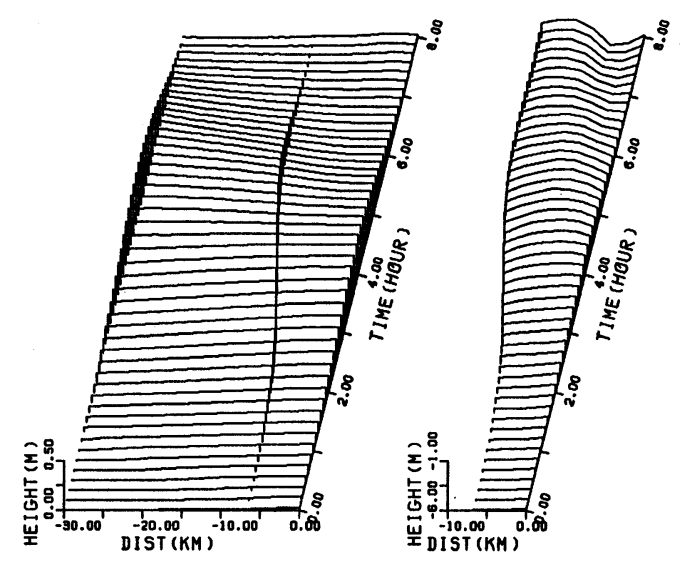

図4.表面（左）と界面（右）の形の時間変化
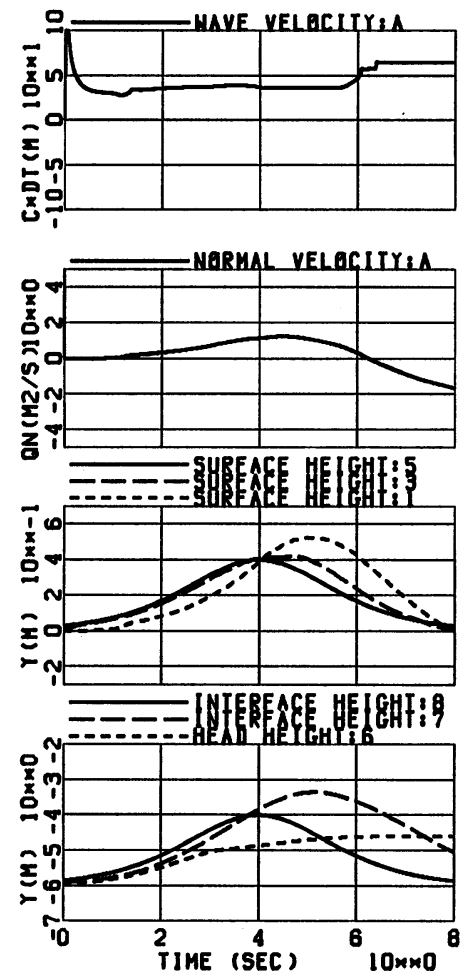

図5. 波速, 水平流速，水位，界面高の 時間変化

\section{参考文献}

[1] 水田 洋, "Lagrange-Euler混合法による自由表面及び密度界面の数㑷解析”， 第29回水理講演会詥文集, pp.721-726 (1985).

[2] 水田 洋, "Lagrange-Euler混合法による河口密度流の数值解析"，第31回水理講演会詥文集，pp.515-520 (1987).

[3] Y.Mizuta, "A Deformable-Cell Method Used for Incompressible Density Stratified Flows", Proc. Int.Conf. on Computational Method in Flow Analysis held at Okayama, eds. H.Niki and M. Kawahara, Okayama Univ. of Science, pp.373-380 (1988).

[4] Y.Mizuta, "Generalized Boundary Conditions on the Basis of a Deformable-Cell Method -Free Surfaces, Density Interfaces and Open Boundaries-", Proc. Int.Symp. on Computational Fluid Dynamics-Nagoya, pp.1001-1006 (1989).

[5] P.J.Roache, "Computational Fluid Dynamics", Hermosa Pub. Inc., Albuquerque, New Mexico (1976)

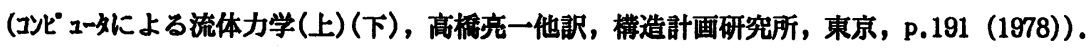

[6] 日野幹雄,仲座栄三, “数值波動解析における新しい無反射境界双一-ムの平面二次元間題への適用”, 第35回海岸工学論文集, pp.262-266 (1988).

[7] 水田 洋, "数値流体解析における開いた境界の基硭的な解析と考察", 第3回数値流体力学汸ボジ ヴ講演詥文集, pp.287-290 (1989). 